\title{
Efficacy of extracts from plants of the Brazilian Pantanal against Rhipicephalus (Boophilus) microplus
}

\author{
Eficácia de extratos de plantas do Pantanal brasileiro sobre Rhipicephalus (Boophilus) microplus \\ Larissa Bezerra dos Santos ${ }^{1}$; Juliana Kátia Souza ${ }^{2}$; Barbara Papassoni²; Dyego Gonçalves Lino Borges ${ }^{1}$; \\ Geraldo Alves Damasceno Junior²; Jeana Mara Escher de Souza²; Carlos Alexandre Carollo²; \\ Fernando de Almeida Borges ${ }^{2 *}$
}

${ }^{1}$ Post-graduation program in Animal Science, Universidade Federal de Mato Grosso do Sul - UFMS, Campo Grande, MS, Brasil

${ }^{2}$ Universidade Federal de Mato Grosso do Sul - UFMS, Campo Grande, MS, Brasil

Received June 4, 2013

Accepted August 26, 2013

\begin{abstract}
This research evaluated the in vitro acaricidal activity of extracts from 21 plant species from the Pantanal of Mato Grosso do Sul. During stage I, a larval immersion test was performed using three extract concentrations (5\%, 20\%, and $40 \%$ ). During stage II, we used only plants that showed over $95 \%$ efficiency at the $40 \%$ concentration in stage I in an amount sufficient for the adult immersion test. Aeschynomene denticulata, Angelonia hirta, Aspilia latissima, Caperonia castaneifolia, Centratherum punctatum, Crotalaria micans, Diodia kuntzei, Echinodorus paniculatus, Hyptis mutabilis, Lantana canescens, Melanthera latifolia, Ocotea diospyrifolia, Richardia grandiflora, Sebastiana hispida, Tocoyena formosa, Zanthoxylum rigidum, and Sesbania virgata (fruit extract) showed acaricidal activity against the larval stage of Rhipicephalus (Boophilus) microplus higher than $95 \%$ at a $40 \%(\mathrm{w} / \mathrm{v})$ concentration, while Hippocratea volubilis and Randia armata showed moderate efficacy and Croton glandulosus and Senna obtusifolia had no effect. The M. latifolia, A. hirta, R. grandiflora, and A. latissima raw extracts were evaluated for their activity against adults, and only A. hirta showed an efficacy close to $90 \%$. Eighteen extracts had an efficacy of up to $95 \%$ against larvae at a $40 \%$ concentration, seven extracts were effective at $20 \%$, and only one (Sebastiana hispida) was effective at a $5 \%$ concentration.
\end{abstract}

Keywords: Cattle tick, natural compounds, phytotherapy, parasites.

\section{Resumo}

Este trabalho avaliou a atividade acaricida in vitro de extratos de 21 espécies de plantas do Pantanal de Mato Grosso do Sul. Na etapa I, foi realizado um teste de imersão larval utilizando três concentraçôes de extrato $(5 \%, 20 \%$ e 40\%). Na etapa II, utilizou-se apenas as plantas que apresentaram eficácia superior a $95 \%$, na concentração de $40 \%$ na etapa I e que apresentasse quantidade suficiente para o teste de imersão de adulto. Aeschynomene denticulata, Angelonia hirta, Aspilia latissima, Caperonia castaneifolia, Centratherum punctatum, Crotalaria micans, Diodia kuntzei, Echinodorus paniculatus, Hyptis mutabilis, Lantana canescens, Melanthera latifolia, Ocotea diospyrifolia, Richardia grandiflora, Sebastiana hispida, Tocoyena formosa, Zanthoxylum rigidum e Sesbania virgata (extrato do fruto) apresentaram atividade acaricida sobre larvas de Rhipicephalus (Boophilus) microplus superior a 95\% na concentração de $40 \%$ (w/v), enquanto Hippocratea volubilis e Randia armata apresentaram eficácia moderada e Croton glandulosus e Senna obtusifolia não apresentaram efeito acaricida. Os extratos brutos de M. latifolia, A. hirta, R. grandiflora e A. latissima foram avaliados sobre adultos e $A$. hirta apresentou eficácia próxima de $90 \%$. Dezoito extratos apresentaram eficácia de até $95 \%$, contra larvas, na concentração de $40 \%$, sete extratos foram eficazes a $20 \%$ e apenas um (Sebastiana hispida) foi eficaz na concentração de $5 \%$.

Palavras-chave: Carrapato bovino, compostos naturais, fitoterapia, parasitas.

\footnotetext{
${ }^{*}$ Corresponding author: Fernando de Almeida Borges

Universidade Federal de Mato Grosso do Sul - UFMS, Av. Senador Filinto

Müller, 2443, Ipiranga, CP 549, CEP 79074-460, Campo Grande, MS, Brasil

e-mail: fernando.borges@ufms.br
} 


\section{Introduction}

The resistance of $R$. (B.) microplus to almost every chemical group in Mato Grosso do Sul State has been demonstrated; this situation is detrimental to Brazil as a whole (GOMES et al., 2011) and affects several other countries (FAO, 2004). Due to this reduction in the susceptibility to current acaricidals, there has been an increase in the development of studies using natural products to search for new active ingredients (NEEWMAN; CRAGG, 2012). A survey of the records from the United States Environmental Protection Agency between 1997 and 2010 shows that 69.3\% of the new pesticide registrations originated from research on natural products; the success of several of these substances is what sustains this type of research (CANTRELL et al., 2012).

In Brazil, several plants have been evaluated against $R$. (B) microplus, highlighting Melia azadirachta (SOUSA et al., 2008), Azadirachta indica (COSTA et al., 2008), Drimys brasiliensis (RIBEIRO et al., 2008b), Piper aduncum (SILVA et al., 2009), Simarouba versicolor (CATTO et al., 2009), Calea serrata (RIBEIRO et al., 2011), Tagetes minuta (GARCIA et al., 2012) and Guarea kunthiana (BARBOSA et al., 2013).

Nineteen plants were evaluated for the first time with respect to their acaricidal activity in this study, and only two of the 21 species (Croton glandulosus and Sebastiana hispida) had already been evaluated by Catto et al. (2009) in relation to $R$. (B.) microplus.

The use of phytotherapies to control ticks is a major challenge; however, given the great diversity of plants found in the Pantanal bioma (Brazil), this approach represents a feasible alternative. The objective of this study was to evaluate 21 species from 12 different families of plants from the Federal University of Mato Grosso do Sul (UFMS) Plant extracts collection to identify candidate for new synthetic acaricidal drug screening.

\section{Materials and Methods}

\section{Isolate of $R$. (B.) microplus}

A field isolate of $R$. (B.) microplus resistant to a pyrethroid (deltamethrin) was used. The acaricidal profile of this isolate also showed resistance to organophosphate and pyrethroid association (ethion and cypermethrin, chlorpyrifos and cypermethrin) and organophosphate and organophosphate association (dichlorvos and chlorpyrifos) and sensitivity to amidine (amitraz). This isolate originated from the Federal University of Uberlândia, granted by Embrapa Gado de Corte. For their maintenance, 5000 larvae of $R$. (B.) microplus were infested over a calf on a weekly basis. All procedures followed the biosafety, ethics and welfare requirements for animal research, established by the Animal Ethics Committee from the Federal University of Mato Grosso do Sul (UFMS) under process number 410/2012.

\section{Plant material}

Twenty-one plant species were collected (different parts) (Table 1) from the area of Rio Miranda/Abobral, at São Miguel Farm (1936' 30" S; $\left.15157^{\circ} 2^{\prime} 8^{\prime \prime} \mathrm{W}\right)$, Estrada Parque (19 $37^{\prime}$ $5^{\prime \prime}$ S; $\left.57^{\circ} 2^{\prime} 4^{\prime \prime} \mathrm{W}\right)$, Base de Estudos do Pantanal - UFMS (19 $\left.34^{\prime} 36^{\prime \prime} \mathrm{S} ; 57^{\circ} 1^{\prime} 11^{\prime \prime} \mathrm{W}\right)$ and São Bento Farm (19 34' 7" S; $57^{\circ}$ 1' 15" O) during the flood season (December to March) of 2012, with access and sample shipment authorization under the Brazilian Genetic Heritage Component number 010457/2010-0. The criteria for the species choice were the amount of material available for evaluation and the family to which the species belonged. Of the 12 evaluated families, some showed previously identified acaricidal action, while others were unstudied.

The plant materials were dried, pulverized, sieved and stored in sealed vials $\left(-12^{\circ} \mathrm{C}\right)$ until preparation of the extracts (maximum elapsed time of three months), which were also stored at the same temperature until the in vitro tests

The samples stored was extracted with a pressurized fluid extractor (DIONEX ${ }^{\circledR}$ ) (ASE 150) using the raw method: solvent (ethanol/distilled water 7:3), $100{ }^{\circ} \mathrm{C}, 1,600 \mathrm{psi}$, one cycle, static time of $5 \mathrm{~min}, 60 \%$ wash, and $50 \mathrm{sec}$ of purging.

\section{Larval immersion test (LIT)}

Twenty-two hydroalcoholic raw extracts were evaluated, which were taken from the twenty-one plants of the Pantanal of Mato Grosso do Sul (one species had two extracts, one from its fruit and the other from its thin branches and leaves) listed in Table 1. These extracts were tested at three different concentrations (40\%, $20 \%$ and $5 \%$ ) in triplicate using the larval immersion test (LIT) (Klafke, 2006) with modifications.

Briefly, 0.025 grams of eggs were weighed and kept in $2 \mathrm{~mL}$ polypropylene tubes at $27{ }^{\circ} \mathrm{C} \pm 1$, which were adapted with an orifice on the lid for free air exchange so that the treatments could be injected.

The diluents used for the in vitro evaluations were determined by the polarity and water solubility of the raw extracts: $20 \%$ ethanol, $5 \%$ Tween 80 or distilled water. Immediately after $1 \mathrm{~mL}$ of the diluted extracts was added to the polypropylene tubes containing approximately 500 larvae ( 0.025 grams of eggs), the tube was closed and shaken manually for a few seconds and then at $200 \mathrm{rpm}$ in a shaker for 10 minutes. After this period, the larvae were placed in filter paper envelopes using a brush, and the envelopes were fastened with paper clamps and kept at $27^{\circ} \mathrm{C} \pm 1$ and $80 \%$ relative humidity. After 24 hours, the live and dead larvae were counted. For each extract, a positive control (cypermethrin, dichlorvos, and citronellal according to the concentrations recommended by the manufacturer, Colosso Pulverização ${ }^{\circledR}$ - Ourofino Saúde Animal) and a negative control (20\% ethanol, 5\% Tween 80 or distilled water) were used.

\section{Adult immersion test (AIT)}

The raw extracts from the following plants, M. latifolia, $A$. hirta, $R$. grandiflora, and A. latissima, were used for the AIT 
Table 1. Plants collected in the region of the Pantanal of Mato Grosso do Sul that were used in the Larval Immersion Test (LIT) and the Adult Immersion Test (AIT), listing the families and parts of the plants collected.

\begin{tabular}{|c|c|c|c|}
\hline $\begin{array}{r}\text { Species } \\
\end{array}$ & Family & Popular Name & Collected Part \\
\hline Aeschynomene denticulata & Leguminosae & Angiquinho & $\mathrm{AP} / \mathrm{FL} / \mathrm{FR}$ \\
\hline Angelonia hirta & Scrophulariace & - & $\mathrm{AP} / \mathrm{FL} / \mathrm{FR}$ \\
\hline Aspilia latissima & Asteraceae & Mirassol; fumeiro & LE \\
\hline Caperonia castaneifolia & Euphorbiaceae & Castanheiro-do-brejo & $\mathrm{AP} / \mathrm{FL}$ \\
\hline Centratherum punctatum & Asteraceae & Balaio-de-velho & $\mathrm{AP} / \mathrm{FL}$ \\
\hline Crotalaria micans & Leguminosae & Guizo-de-cascavel & $\mathrm{AP} / \mathrm{FL} / \mathrm{FR}$ \\
\hline Croton glandulosus & Euphorbiaceae & Anxuma & $\mathrm{AP} / \mathrm{FL}$ \\
\hline Diodia kuntzei & Rubiaceae & - & $\mathrm{TP} / \mathrm{FL}$ \\
\hline Echinodorus paniculatus & Alismataceae & Chapéu-de-couro & $\mathrm{AP} / \mathrm{FL}$ \\
\hline Hippocratea volubilis & Hippocrateaceae & Cipó borracha & TB/LE \\
\hline Hyptis mutabilis & Lamiaceae & Betônica-brava & $\mathrm{AP} / \mathrm{FL}$ \\
\hline Lantana canescens & Verbenaceae & Camara and Cidreira & $\mathrm{AP} / \mathrm{FL}$ \\
\hline Melanthera latifolia & Asteraceae & - & $\mathrm{AP} / \mathrm{FL}$ \\
\hline Ocotea diospyrifolia & Lauraceae & Canela-preta & TB/LE \\
\hline Randia armata & Rubiaceae & Limão-bravo & TB/LE/FR \\
\hline Richardia grandiflora & Rubiaceae & Trevo-mexicano & $\mathrm{AP} / \mathrm{FL}$ \\
\hline Sebastiana hispida & Euphorbiaceae & Mercúrio & $\mathrm{AP}$ \\
\hline Sesbania virgata & Fabaceae & - & TB/LE \& FR \\
\hline Senna obtusifolia & Leguminosae & Fedegoso & $\mathrm{AP} / \mathrm{FL} / \mathrm{FR}$ \\
\hline Tocoyena formosa & Rubiaceae & Genipapinho & TB/LE \\
\hline Zanthoxylum rigidum & Rutaceae & Mama de cadela & TB/LE \\
\hline
\end{tabular}

Abbrev.: TB: thin branches; AP: aerial part (including the leaf, branch and stem); TP: total part (including the root, leaf and thin branches); FL: flower; FR: fruit; LE: leaf.

(DRUMMOND et al., 1973) because only these four species had a sufficient amount of extract to perform the AIT in relation to other extracts that were also effective in the LIT. The tests were performed in duplicate ( 10 females per group, $\mathrm{N}=20$ /concentration, homogeneously distributed among the repetitions) to study the effects of different concentrations on the mortality and reproductive aspects of the females. The same positive and negative controls previously mentioned were used.

\section{Data analysis}

To calculate the efficiency on larvae, we used:

$\mathrm{E} \%=\left[\frac{\text { Average of dead larvae }}{(\text { Average of live larvae }+ \text { Average of dead larvae })}\right] \times 100$

The reproductive efficiency (ER) and efficiency index (IE) of the plant extract in adult engorged females were calculated according to Drummond et al. (1973):

$\mathrm{ER}=\left(\frac{\text { Egg mass weight }}{\text { Female mass weight }}\right) \times \%$ hatching $\times 20,000$

$\mathrm{IE}=\left[\frac{(\text { ER from control group }- \text { ER from treated group })}{\text { ER from control group }}\right] \times 100$

The evaluation criteria for the extracts were established according to the guidelines of the World Association for the Advancement of Veterinary Parasitology (WAAVP) (HOLDSWORTH et al., 2006) to evaluate the acaricidal efficiency and specified an efficacy greater than $95 \%$.

\section{Results}

The efficiency percentages for the LIT at concentrations of $40 \%, 20 \%$, and 5\% are listed in Table 2 .

Overall, twelve extracts presented 100\% efficiency at a $40 \%$ concentration, seven extracts presented an efficiency equal to or greater than $95 \%$ at a $20 \%$ concentration, one extract presented an efficiency greater than $95 \%$ at a $5 \%$ concentration, and two extracts, $S$. obtusifolia and $C$. glandulosus, were considered inefficient against $R$. (B.) microplus because they presented less than $95 \%$ efficiency at the highest concentration evaluated in this study $(40 \%)$.

The effects of the extracts on the adult females of $R$. (B.) microplus are presented in Table 3. A. hirta (40\%) presented 5\% mortality, with an average egg hatchability of $19.3 \%$, and reached an average efficiency of $88 \%$. M. latifolia (40\%) presented $35 \%$ mortality and an average hatchability of $47.6 \%$. $R$. grandiflora (40\%) presented $15 \%$ mortality and an average hatchability of 45.3\%. A. latissima (50\%) presented $10 \%$ mortality and an average hatchability of $33.3 \%$.

\section{Discussion}

This study is the first evaluation of the acaricidal activity of $A$. denticulata, A. hirta, A. latissima, C. castaneifolia, C. punctatum, C. micans, D. kuntzei, E. paniculatus, $H$. volubilis, $H$. mutabilis, $L$. canescens, $M$. latifolia, $O$. diospyrifolia, $R$. armata, $R$. grandiflora, S. virgata, S. obtusifolia, $T$. formosa and $Z$. rigidum, which all colleted at the Pantanal region of Mato Grosso do Sul. Two plants 
Table 2. Average efficiency percentage for the Larval Immersion Test (LIT) at three concentrations, performed in triplicate on $R$. (B.) microplus larvae.

\begin{tabular}{|c|c|c|c|c|c|}
\hline \multirow{2}{*}{ Species } & \multicolumn{3}{|c|}{ Efficacy (\%)/extract concentration } & \multirow{2}{*}{ Negative control } & \multirow{2}{*}{ Positive control } \\
\hline & $5 \%$ & $20 \%$ & $40 \%$ & & \\
\hline Aeschynomene denticulata & $2(1.2-2.4)$ & $100(100-100)$ & $100(100-100)$ & $1.67(0.9-2.6)$ & 100 \\
\hline Angelonia hirta & $9.93(8-10.9)$ & $97.26(96.4-97.9)$ & $100(100-100)$ & $1(0-2.4)$ & 100 \\
\hline Aspilia latissima & $5.84(2.8-8.6)$ & $46.14(38.4-53.3)$ & $97.88(92.9-100)$ & $1.03(0-2.4)$ & 100 \\
\hline Caperonia castaneifolia & $15.16(6.1-20.8)$ & $61.45(46.7-61)$ & $100(100-100)$ & $1(0-2.4)$ & 100 \\
\hline Centratherum punctatum & $1.74(0.7-2.5)$ & $98.3(91.4-98.9)$ & $100(100.100)$ & $0.83(0.6-1.3)$ & 100 \\
\hline Crotalaria micans & $4.7(0.3-6.8)$ & $75(70.4-80.3)$ & $100(100-100)$ & $1.67(0.9-2.6)$ & 100 \\
\hline Croton glandulosus & $9.23(6.1-15.6)$ & $12.16(9-15.7)$ & $45.97(29.7-58.7)$ & $2.8(1.9-3.5)$ & 100 \\
\hline Diodia kuntzei & $11.07(3.6-23)$ & $88.53(88.3-89)$ & $100(100-100)$ & $1.37(0.7-2)$ & 100 \\
\hline Echinodorus paniculatus & $5.21(3.8-6.9)$ & $100(100-100)$ & $100(100-100)$ & $1.37(0.7-2)$ & 100 \\
\hline Hippocratea volubilis & $4(2.9-4.2)$ & $43(41.2-44.5)$ & $84(82.7-86.8)$ & $0(0-0)$ & 100 \\
\hline Hyptis mutabilis & $5(3.9-8.7)$ & $78(71.4-87.9)$ & $95(87-100)$ & $1.3(0.9-1.8)$ & 100 \\
\hline Lantana canescens & $22.27(3.4-55.6)$ & $63.82(47-77.2)$ & $99.63(98.6-100)$ & $1.03(0-2.4)$ & 100 \\
\hline Melanthera latifolia & $2.93(1.9-4.1)$ & $76.49(64-87.7)$ & $100(100-100)$ & $0.83(0.6-1.3)$ & 100 \\
\hline Ocotea diospyrifolia & $5(3.4-6.4)$ & $64(58-69.8)$ & $98(97.5-99)$ & $0(0-0)$ & 100 \\
\hline Randia armata & $25(18.6-32.7)$ & $28(22.7-36.7)$ & $75(67.2-79.8)$ & $2.8(1.9-3.5)$ & 100 \\
\hline Richardia grandiflora & $4(3-5.8)$ & $39(34.6-43.3)$ & $100(100-100)$ & $1(0-1.9)$ & 100 \\
\hline Sebastiana hispida & $99.11(99-100)$ & $100(100-100)$ & $100(100-100)$ & $1.37(0.7-2)$ & 100 \\
\hline Sesbania virgata $\mathrm{TB} / \mathrm{LE}$ & $3.16(2.4-4.4)$ & $46.01(41.1-59.9)$ & $96.52(98.6-100)$ & $1.03(0-2.4)$ & 100 \\
\hline Sesbania virgata $\mathrm{FR}$ & $84.26(80.9-91)$ & $98.69(98.7-100)$ & $100(100-100)$ & $1(0-2.4)$ & 100 \\
\hline Senna obtusifolia & $11(8.1-14)$ & $20(15-25.6)$ & $40(26.6-53.4)$ & $2.8(1.9-3.5)$ & 100 \\
\hline Tocoyena formosa & $5(4.2-6)$ & $35(30.6-40)$ & $95(90-99.5)$ & $1.3(0.9-1.8)$ & 100 \\
\hline Zanthoxylum rigidum & $3(2.3-4.7)$ & $99(98-100)$ & $100(100-100)$ & $1(0-1.9)$ & 100 \\
\hline
\end{tabular}

Abbrev.: TB: thin branches AP: aerial part (including the leaf, branch and stem); PT: total part (including the root, leaf and thin branches); FL: flower; FR: fruit; LE: leaf. For each extract, a positive control (cypermethrin, dichlorvos, and citronellal at the concentrations recommended by the manufacturer, OUROFINO ${ }^{\circledR}$ ) and a negative control ( $20 \%$ ethanol, $5 \%$ Tween 80 or distilled water) were used.

Table 3. Average of the acaricidal efficiency of the raw extracts of plants from the Pantanal region of Mato Grosso do Sul, on $R$. (B.) microplus in the Adult Immersion Test (AIT). Tests performed in duplicate, with 10 females per group.

\begin{tabular}{|c|c|c|c|}
\hline \multicolumn{4}{|c|}{ Adult Immersion Test } \\
\hline \multicolumn{2}{|c|}{ Angelonia birta } & \multicolumn{2}{|c|}{ Melanthera latifolia } \\
\hline Concentration \% & Efficiency Average & Concentration \% & Efficiency Average \\
\hline $40 \%$ & 88 & $40 \%$ & 73 \\
\hline $20 \%$ & 85 & $20 \%$ & 35 \\
\hline $10 \%$ & 77 & $10 \%$ & 32 \\
\hline $5 \%$ & 57 & $5 \%$ & 17.4 \\
\hline $2.50 \%$ & 40 & $2.50 \%$ & 19 \\
\hline $1.25 \%$ & 17 & $1.25 \%$ & 17 \\
\hline $0.63 \%$ & 8 & $0.63 \%$ & 0 \\
\hline $0.31 \%$ & 6 & $0.31 \%$ & 0 \\
\hline Positive control & 100 & Positive control & 100 \\
\hline Negative control & 0 & Negative control & 0 \\
\hline \multicolumn{2}{|c|}{ Richardia grandiflora } & \multicolumn{2}{|c|}{ Aspilia latissima } \\
\hline Concentration \% & Efficiency Average & Concentration \% & Efficiency Average \\
\hline $40 \%$ & 63 & $50 \%$ & 76 \\
\hline $20 \%$ & 53 & $25 \%$ & 52 \\
\hline $10 \%$ & 30 & $12.50 \%$ & 23 \\
\hline $5 \%$ & 18 & $6.25 \%$ & 27 \\
\hline $2.50 \%$ & 7 & $3.13 \%$ & 17 \\
\hline $1.25 \%$ & 8 & $1.56 \%$ & 8 \\
\hline $0.63 \%$ & 2 & $0.78 \%$ & 15 \\
\hline $0.31 \%$ & 0 & $0.39 \%$ & 6 \\
\hline Positive control & 100 & Positive control & 100 \\
\hline Negative control & 0 & Negative control & 0 \\
\hline
\end{tabular}

For each extract, a positive control (cypermethrin, dichlorvos, and citronellal at the concentrations recommended by the manufacturer, OUROFINO ${ }^{\circledR}$ ) and a negative control (20\% ethanol, $5 \%$ Tween 80 or distilled water) were used. 
used in this study, C. glandulosus and S. hispida, had already been evaluated with respect to their acaricidal activity (CATTO et al., 2009). In this study, the C. glandulosus extract was obtained using only the aboveground parts of the plant, and it was found to have $9.23 \%$ efficacy compared to $R$. (B.) microplus larvae at a $5 \%$ concentration. Catto et al. (2009) used the whole plant to obtain the extract and evaluated it at a $2.5 \%$ concentration, which is lower than the concentration used in this study, on adults of the same tick species; they observed a hatchability of $89 \%$ and an average efficiency of $20.28 \%$. These results showed that $C$. glandulosus has a reduced action against $R$. (B.) microplus that occurs mainly when the engorged females are laying eggs and when there is a possible compromise of embryogenesis.

In this paper, the hydroalcoholic extract prepared from the aboveground part of $S$. hispida was obtained, which presented an efficacy greater than $95 \%$ at a $5 \%$ concentration in the LIT. In another study, the raw extract of the whole plant at a concentration of $2.5 \%$ was evaluated in the AIT, and the average efficiency was only $8.16 \%$, with a reduction in egg hatchability of 7\% (CATTO et al., 2009). This difference in the acaricidal action of $S$. hispida may be justified by the interference of factors such as the location and time of collection, the part of the plant used, and the life stage of the tick being treated. Catto et al. (2009) obtained the exsiccate in April 2008, a year when there was a severe drought and low precipitation indices (SOARES et al., 2009). The exsiccate for this study was obtained during the flood season in Pantanal in the summer of 2012 (December to March). According to GobboNeto et al. (2007), the secondary compounds of plants may be influenced by seasonality, circadian rhythm and development; in the case of an extended drought, the stress to which the plant is submitted decreases the concentration of metabolites, and these substances may accumulate in the whole plant or part of it during the summer. In addition, the methods used to extract the active ingredients differed between these studies. Catto et al. (2009) used maceration as an extraction method to obtain a tincture, followed by drying (evaporation of the solvent). Considering that the success of this method depends on the extracting liquid, temperature, shaking, $\mathrm{pH}$ and extraction time, in this study, closed system extraction in a pressurized fluid extractor was performed. This extraction method is considered highly efficient and uses a lower amount of solvent compared with other extraction methods (FALKENBERG et al., 2010).

$Z$. rigidum (Rutaceae) at a $20 \%$ concentration presented with an efficiency average of $99 \%$. The Rutaceae family has been extensively studied with respect to the significant number of different secondary metabolites and its biological activities - antibacterial, fungicidal (NISSANKA et al., 2001) and acaricidal (ELANGO; RAHUMAN, 2011). The Zanthoxylum genus includes species with anti-fungicidal and repellent activity against Aedes aegypti (CHOOCHOTE et al., 2007).

M. latifolia, A. latissima and C. punctatum (Asteraceae) presented efficacy greater than $95 \%$ at the highest concentration (40\%) in the literature. Ribeiro et al. (2008a) also observed an efficiency of greater than 95\% for Calea serrata (Quebra-tudo), a plant that also belongs to the Asteraceae family. The hexane extract from C. serrata (aboveground parts of the plant), which is rich in eupatoriochromene and precocene II, presented a toxic effect in the LIT (concentrations of 3.12 and $6.25 \mathrm{mg} / \mathrm{mL}$ ) against $R$. (B.) microplus. Later, Ribeiro et al. (2012) analyzed the mechanism of action of the hexane extract from C. serrata (concentrations of $1.5,3$ and $6 \mathrm{mg} / \mathrm{mL}$ ), and the results showed the inhibition of acetylcholinesterase in $R$. (B.) microplus larvae and in Wistar rats at all concentrations.

In this study, $C$. micans showed $100 \%$ efficacy at a concentration of $40 \%$, and $A$. denticulata presented an efficacy of $100 \%$ at concentrations of $40 \%$ and $20 \%$. Although they belong to the same family (Leguminosae), these two species may contain different secondary metabolites that are present in unequal amounts. These compounds may vary by the state of their growth between its different parts, and they can be activated at any stage of development or during period, so that plants belonging to the same family may have the same classes of substances and yet have different activity levels (MANN, 1987), as reported here for $C$. micans and $A$. denticulata.

Two extracts of $S$. virgata (Fabaceae) were evaluated in this study. The fruit extract showed efficacy higher than 95\% at concentrations of $20 \%$ and $40 \%$, whereas the extract from leaves and thin branches of the plant had the same efficiency only at a $40 \%$ concentration. The main compound in the seeds from the fruit of $S$. virgata is the bioflavonoid (+)-catechin, which has a phytotoxic effect on plants and inhibits the growth of bacteria such as Pseudomonas fluorescens (SIMÓES et al., 2008). This compound may be responsible for the higher efficiency of the fruit extract compared with the extract from the leaves and thin branches and for the antimicrobial action, but another substance may act synergetically (WINK, 2010).

At a concentration of $5 \%$, the raw extracts of $A$. hirta and $M$. latifolia showed higher efficacy against adults than against larvae of $R$. (B.) microplus. $R$. grandiflora was more effective against adults at all evaluated concentrations. This result is in contrast with the observation that $R$. (B.) microplus larvae are apparently more susceptible to both the chemical acaricidals and extracts tested in several studies. Chagas et al. (2003) evaluated the sensitivity of $R$. (B.) microplus to solvent and reported a higher sensitivity in females than in larvae, even with one half of the immersion time compared to the larvae. They also emphasized that this result may be related to the difference in the formation of the cuticle of larvae and adults.

The tick's cuticle is composed of wax, which is present in a larger proportion in adults and has several physiological functions (ODHIAMBO; GALUN, 1982). With the use of a solvent, it is possible to increase the penetration of the plant extract into parasites (CHAGAS et al. 2002), thus increasing its effectiveness. Additionally, there may be a direct action of the solvent on the fitness of the adult tick due to a loss of water to the outside because of the removal of the wax cuticle of the female tick (CHAGAS et al., 2003). This action is less pronounced in larvae (CHAGAS et al., 2002) because the lipid layer appears after the changes in the nymph of $R$. (B.) microplus (ODHIAMBO; GALUN, 1982). In this study, the use of methyl alcohol as a solvent may have increased the susceptibility of females compared to the larvae.

Kaplan et al. (1994), when evaluating the chemical diversity of species from the Brazilian Cerrado, observed that the species from the Cerrado have a large number of secondary compounds 
(bioactive); however, the amount of each compound is so small that the compounds could only be identified by a detailed analysis of the phytochemical profile. Therefore, in this study, the evaluation of high concentrations ( $40 \%$ ) of crude extracts of plants is justifiable for the identification of candidate plant species for future studies aiming at the isolation of bioactive substances.

\section{Conclusion}

Overall, eighteen extracts presented acaricidal activity against the larvae of $R$. (B.) microplus greater than $95 \%$ at a concentration of $40 \%$; seven extracts were effective at a concentration of $20 \%$; and only one, the Sebastiana hispida extract, was effective at a concentration of 5\%. Four plants, Randia armata, Croton glandulosus, Hippocratea volubilis and Senna obtusifolia, presented efficiency less than $95 \%$ at a $40 \%$ concentration. Among the four raw extracts tested in engorged females, only the Angelonia hirta species presented efficiency close to $90 \%$ and reduced hatchability by $80.7 \%$.

\section{References}

Barbosa CS, Borges LMF, Nicácio J, Alves RD, Miguita CH, Violante IMP, et al. In vitro activities of plant extracts from the Brazilian Cerrado and Pantanal against Rhipicephalus (Boophilus) microplus (Acari: Ixodidae). Exp Appl Acarol 2013; 60(3): 421-430. PMid:23344640. http://dx.doi.org/10.1007/s10493-013-9656-z

Cantrell CL, Dayan FE, Duke SO. Natural Products As Sources for New Pesticides. J Nat Prod 2012; 75(6): 1231-1242. PMid:22616957. http:// dx.doi.org/10.1021/np300024u

Catto JB, Bianchin I, Saito M. Efeito acaricida in vitro de extratos de plantas do Pantanal no carrapato de bovinos Rhipicephalus (Boophilus) microplus. Campo Grande: Embrapa Gado de Corte, 2009. Boletim de Pesquisa e Desenvolvimento, n. 26. [cited 2011 Mar 21]. Available from: www. cnpgc.embrapa.br/publicacoes/bp/BP26.

Chagas ACS, Passos WM, Prates HT, Leite RC, Furlong JF, Fortes ICP. Efeito acaricida de óleos essenciais e concentrados emulsionáveis de Eucalyptus spp. em Boophilus microplus. Braz J Vet Res Anim Sci 2002; 39(5): 247-253. http://dx.doi.org/10.1590/S1413-95962002000500006

Chagas ACS, Leite RC, Furlong J, Prates HT, Passos WM. Sensibilidade do carrapato Boophilus microplus a solventes. Cienc Rural 2003;33(1): 109-114. http://dx.doi.org/10.1590/S0103-84782003000100017

Choochote W, Chaithong U, Kamsuk K, Jitpakdi A, Tippawangkosol P, Tuetun B, et al. Repellent activity of selected essential oils against Aedes aegypti. Fitoterapia 2007; 78(5): 359-364. PMid:17512681. http:// dx.doi.org/10.1016/j.fitote.2007.02.006

Costa FB, Vasconcelos PS, Silva AMM, Brandão VM, Silva IA, Teixeira WC, et al. Eficácia de fitoterápicos em fêmeas ingurgitadas de Boophilus microplus, provenientes da mesorregião oeste do Maranhão, Brasil. Rev Bras Parasitol Vet 2008; 17(S1): 83-86. PMid:20059822.

Drummond RO, Ernst SE, Trevino JL, Gladney WJ, Graham OH. Boophilus annulatus and B. microplus: laboratory tests of insecticides. J Econ Entomol 1973; 66(1): 130-133. PMid:4690254.
Elango G, Rahuman AA. Evaluation of medicinal plant extracts against ticks and fluke. Parasitol Res 2011; 108(3): 513-519. PMid:20922419. http://dx.doi.org/10.1007/s00436-010-2090-9

Falkenberg MB, Santos RI, Simôes CMO. Análise fitoquímica. In: Simôes CMO, Schenkel EP, Gosmann G, Mello JCP, Mentz LA, Petrovick PR. Farmacognosia: da planta ao medicamento. 6. ed. UFSC. 2010.

Food and Agriculture Organization - FAO. Guidelines Resistnace Management and Integrated Parasite Control in Ruminants. Module 1: Ticks: Acaricide Resistance: Diagnosis, management and Prevention. Rome: FAO, Animal Production and Health Division; 2004. p. 1-53.

Garcia MV, Matos J, Barros JC, De Lima DP, Lopes RS, Andreotti R. Chemical identification of Tagetes minuta Linnaeus (Asteraceae) essential oil and its acaricidal effect on ticks. Rev Bras Parasitol Vet 2012; 21(4): 405-411. PMid:23295821. http://dx.doi.org/10.1590/S198429612012000400011

Gobbo-Neto L, Lopes NP. Plantas medicinais: fatores de influência no conteúdo de metabólitos secundários. Quim Nova 2007; 30(2): 374-381. http://dx.doi.org/10.1590/S0100-40422007000200026

Gomes A, Koller WW, Barros IATM. Suscetibilidade de Rhipicephalus (Boophilus) microplus a carrapaticidas em Mato Grosso do Sul, Brasil. Cienc Rural 2011; 41(8): 1447-1452. http://dx.doi.org/10.1590/S010384782011005000105

Holdsworth PA, Kemp D, Green P, Peter RJ, De Bruin C, Jonsson $\mathrm{NN}$, et al. World Association for the Advacement of Veterinary Parasitology (W. A. A. V. P.) Guidelines for evaluating the efficacy of acaricides against ticks (Ixodidae) on ruminants. Vet Parasitol 2006; 136(1): 29-43. PMid:16377090. http://dx.doi.org/10.1016/j. vetpar.2005.11.011

Kaplan MAC, Figueiredo MR, Gottlieb OR. Chemical diversity of plants from Brazilian Cerrados. An Acad Bras Ciênc 1994; 66 (S 1 - parte I): 50-55 ou 49-53.

Klafke GM, Sabatini GA, Albuquerque JRM, Kemp DH, Miller RJ, Schumaker TTS. Larval immersion tests with ivermectin in populations of the cattle tick Rhipicephalus (Boophilus) microplus (Acari: Ixodidae) from State of Sao Paulo, Brazil. Vet Parasitol 2006; 142(3-4): 386-390. PMid:16904265. http://dx.doi.org/10.1016/j.vetpar.2006.07.001

Mann J. Secondary metabolism. 2nd ed. Oxford: Clarendon, 1987.374 p.

Neewman DJ, Cragg GM. Natural products as sources of new drugs over the 30 years from 1981 to 2010. J Nat Prod 2012; 75 (3):311-335. PMid:22316239 PMCid:PMC3721181. http://dx.doi.org/10.1021/ np200906s

Nissanka AP, Karunaratne V, Bandara BM, Kumar V, Nakanishi T, Nishi M, et al. Antimicrobial alkaloids from Zanthoxylum tetraspermum and caudatum. Phytochemistry 2001; 56(8): 857-861. http://dx.doi. org/10.1016/S0031-9422(00)00402-7

Odhiambo TR, Galun R. Current themes in tropical science: Volume 1. Physiology of ticks. Oxford: Pergamon, 1982.

Ribeiro VLS, Avancini C, Gonçalves K, Toigo E, Von Poser G. Acaricidal activity of Calea serrata (Asteraceae) on Boophilus microplus and Rhipicephalus sanguineus. Vet Parasitol 2008a; 151(2-4): 351-354. PMid:18158216. http://dx.doi.org/10.1016/j.vetpar.2007.11.007

Ribeiro VLS, Rolim V, Bordignon S, Henriques AT, Dorneles GG, Limberger RP, et al. Chemical composition and larvicidal properties of the essential oils from Drimys brasiliensis Miers (Winteraceae) on the cattle tick Rhipicephalus (Boophilus) microplus and the brown dog 
tick Rhipicephalus sanguineus. Parasitol Res 2008b; 102(3): 531-535. PMid:18046578. http://dx.doi.org/10.1007/s00436-007-0799-x

Ribeiro VLS, Santos JP, Martins JR, Schripsema JS, Siqueira IR, Von Poser GL, et al. Acaricidal properties of the essential oil and precocene II obtained from Calea serrata (Asteraceae) on the cattle tick Rhipicephalus (Boophilus) microplus (Acari: Ixodidae). Vet Parasitol 2011; 179(1-3): 195198. PMid:21402447. http://dx.doi.org/10.1016/j.vetpar.2011.02.006

Ribeiro VLS, Vanzella C, Moysés FS, Santos GC, Martins JRS, Von Poser GL, et al. Effect of Calea serrata Less. $n$-hexane extract on acetylcholinesterase of larvae ticks and brain Wistar rats. Vet Parasitol 2012; 189(2-4): 322-326. PMid:22608349. http://dx.doi.org/10.1016/j. vetpar.2012.04.033

Silva WC, Martins JR, De Souza HE, Heinzen H, Cesio MV, Mato M, et al.Toxicity of Piper aduncum L. (Piperales: Piperaceae) from the Amazon forest for the cattle tick Rhipicephalus (Boophilus) microplus (Acari: Ixodidae). Vet Parasitol 2009; 164(2-4): 267-274. PMid:19573994. http://dx.doi.org/10.1016/j.vetpar.2009.06.006
Simôes K, Du J, Kretzschmar FS, Broeckling CD, Stermitz FS, Vivanco JM, et al. Phytotoxic catechin leached by seeds of the tropical weed Sesbania virgata. J Chem Ecol 2008; 34(5): 681-687. PMid:18427901. http://dx.doi.org/10.1007/s10886-008-9443-1

Soares MTS, Soriano BMA, Santos SA. Monitoramento do comportamento do Rio Paraguai no Pantanal Sul-Mato-Grossense-2008/2009. Corumbá: Embrapa Pantanal; 2009. Comunicado técnico, n. 80.

Sousa LAD, Soares SF, Pires HB Jr, Ferri PH, Borges LMF. Avaliação da eficácia de extratos oleosos de frutos verdes e maduros de cinamomo (Melia azedarach) sobre Rhipicephalus (Boophilus) microplus (Acari: Ixodidae). Rev Bras Parasitol Vet 2008; 17(1): 36-40. PMid:18554439.

Wink M. Secondary Metabolites: Deterring Herbivores. Universidade de Heidelberg; 2010 [cited 2012 Dec 12]. Available from: http:// onlinelibrary.wiley.com/doi/10.1002/9780470015902.a0000918. pub2/full. 